\title{
Exploration of Preservatives that Inhibit Wood Feeding by Inhibiting Termite Intestinal Enzyme Activity ${ }^{1}$
}

\author{
Jeung-Min $\mathrm{LEE}^{2} \cdot$ Young Hee $\mathrm{KIM}^{2}$ - Jin Young $\mathrm{HONG}^{2}$ • \\ BoA LIM ${ }^{2} \cdot$ Ji Hee PARK (D) ${ }^{2, \dagger}$
}

\begin{abstract}
In Korea, damages to wooden cultural properties by termites have been reported all over the country, including Ulleungdo Island and Jeju Island. In order to reduce the damage caused by termites, most cultural properties damaged by them are treated with fumigation or drug treatment on the soil to kill or repel them. The number of treatments is decreasing due to cost and safety problems, and new methods needed to cope with this situation. After extracting an enzyme by selecting only worker termites from the termites collected in Shinan, Jeonnam, as a result of measuring the enzyme activity using xylan of cellulose and hemicellulose that are the components of wood, the activity of termite intestinal enzymes in xylan was higher than that of cellulose having a high molecular weight. Therefore, in this study, as a result of exploring over 600 species of medicinal plant extracts that inhibit the activity of termite intestinal enzymes using xylan as a substrate, the inhibitory effect was significant in Borneolum Syntheticum, Ephedra sinica, and Menthol. Selected Borneolum Syntheticum, Ephedra sinica, and Menthol's extracts not only inhibited the activity of termite intestinal enzymes, but also confirmed that they have insecticidal activation and inhibitory effects on feeding in the result of the direct treatment.
\end{abstract}

Keywords: termite, Borneolum Syntheticum, Ephedra sinica, Menthol, medicinal plant

\section{INTRODUCTION}

In terms of termite distribution in Korea, Reticulitermes speratus kyushuensis account for the majority, but recently, Reticuliternes kanmonensis have been discovered, and damages to buildings by termites have been reported in the country including Ulleungdo Island and Jeju Island (National Research Institute of Cultural Heritage, 2016). Termite's activity usually starts in March and they have a usual habit of moving deep into the soil with a decrease in temperature from October to November, but in wooden buildings where humans live, it was confirmed that termites are active in winter due to internal heating, thereby rapidly increasing the damage (Wu et al., 2019).

In the case of temples or Seowons, they are vulnerable to the damages by termites and microorganisms depending on the layout of buildings and the size of buildings, and pest control or repair, etc. is performed depending on the degree of damage. In the case of

${ }^{1}$ Date Received March 31, 2020, Date Accepted April 29, 2020

2 Department of Restoration Technology Division, National Research Institute of Cultural Heritage, Daejeon 34122, Republic of Korea

† Corresponding author: Ji Hee PARK (e-mail: siesta44@korea.kr, ORCID: 0000-0001-9143-3239) 
severe damage, the method of restoring the building with new materials is used, or the method of restricting the termite access by treating the surrounding soil with drugs is used, but it has issues involving restoration cost and increased processing time. When the damage is in the early stages, people apply fumigation or insect repellents to the building or are responding by confirming whether or not the termites are active by installing a termite trap (Chung et al., 2015; Hadi et al., 2020). However, if termite traps are poorly managed, there is a risk that they can be used as a base for the induced termites, and drugs used in fumigation and insect repellent treatment are mostly chemicals that damage the human body. Thus they are less frequently used, and new methods are needed to supplement them.

Wood, which is the main feeding target of termites, has a structurally solid structure in the cell wall of plants and is composed of cellulose, hemicellulose, and lignin, etc. as components of the cell wall (Cosgrove, 2005; Terrett and Dupree, 2019). Among them, cellulose and hemicellulose are polysaccharides, which are classified according to the type of sugar and the bonding chain. Cellulose is a polysaccharide consisting of a straight chain of D-glucose. There is no spiral or side chain, and hydroxyl groups in the chain form hydrogen bonds, which makes the bond firm and strong. On the other hand, hemicellulose is a polysaccharide composed of several saccharides such as xylose, maltose, and galactose as well as glucose, and unlike cellulose, many side chains are formed in it, so the bond is flexible. Hemicellulose is decomposed by Wood decay fungi or microorganisms present in the gut of insects and is used as an energy source (Aanen, 2006; Ben Guerrero et al., 2015; Tarayre et al., 2015). The intestinal microflora decomposes wood fed by termites into low-molecular sugars and uses it as an energy source. At this time, it is thought that the enzyme activity of these microorganisms also affects the wood-feeding rate (Mun and Nicholas, 2017).
Therefore, in this study, we tried to identify the mechanism of action by activating the termite intestinal enzymes and the substrate, the main component of the cell wall, and to screen the extracts of medicinal plants that inhibit the mechanism of action. Medicinal plant extracts were collected from about 600 medicinal plants native to Korea, China, and Japan.

By selecting an extract that inhibits enzyme activity in the intestines of the termites, the feeding and insecticidal effects of the termites were confirmed through experiments, and the components were analyzed to confirm the possibility as a wood preservative for insecticides and insecticides against termites.

\section{MATERIALS and METHODS}

\subsection{Extracting termite intestinal enzymes and protein quantification}

All termites used in the experiment are Reticulitermes speratus kyushuensis collected in nearby stumps during the investigation of bio-damage related to wooden cultural properties targeting the old house of Kim Hwanki (National Folklore Cultural Heritage No. 251) in Shinan-gun, Jeollanam-do.

The extraction method using solubility was selected as the enzyme extraction method. After selecting worker termites among the termites, ergates that weigh $6.11 \mathrm{~g}$ were frozen at $-40^{\circ} \mathrm{C}$ and crushed, $0.1 \mathrm{M}$ sodium acetate buffer ( $\mathrm{pH}$ 7) was added to the termites for $5 \mathrm{ml}$ per $1 \mathrm{~g}$ of weight, and the enzyme was mixed at room temperature for 24 hours, and then filtered with filter paper and used as termite intestinal enzyme.

To measure the protein content of the extracted termite intestinal enzyme, a quantitative method was selected using the Pierce ${ }^{\mathrm{TM}}$ BCA protein assay kit (Thermo, USA), and bovine serum albumin (BSA) was selected as a protein for comparative quantification. After reacting the termite intestinal enzyme and the comparative protein BSA with the reaction reagent for 
30 minutes at $37{ }^{\circ} \mathrm{C}$ according to the quantitative method, absorbance (562 nm) was measured by Microplate readers (TECAN, CHE). The protein of the termite intestinal enzyme was quantified using the comparative protein BSA content as a standard curve.

\subsection{Measurement of the activity of termite intestinal enzymes against substrates}

To determine the activity of termite intestinal enzymes, cellulose and xylan which is hemicellulose were selected as substrates. To measure the content of reducing sugars to be degraded, a quantitative analysis of reducing sugar by DNS (3,5-dinitrosalicylic acid) method of Miller (1959) was conducted. Miller's DNS reducing sugar experiment is a method of quantifying sugar by measuring the absorbance of 3-amino-5-nitrosalicylic acid produced by reacting reducing sugar to DNS (Miller, 1959). DNS reagents were prepared and used by adding DNS $10.6 \mathrm{~g}$ and $\mathrm{NaOH} 19.8 \mathrm{~g}$ to 1,416 $\mathrm{ml}$ of distilled water, then adding rochelle salts 306 $\mathrm{g}$ and phenol $7.6 \mathrm{~g}$ and $\mathrm{Na}+$ metabisulfite $8.3 \mathrm{~g}$ was added and stirring it for 24 hours.

As a test method for the termite intestinal enzyme activity experiment, add $0.1 \mathrm{M}$ sodium acetate buffer $400 \mu \mathrm{l}$ to substrate $500 \mu \mathrm{l}$ such as cellulose and xylan of $1 \%$ and preheats at $50^{\circ} \mathrm{C}$ with water bath for 1 minute. $100 \mu \mathrm{l}$ of the enzyme was added to the preheated substrate and buffer, and the enzyme and the substrate were reacted at $50{ }^{\circ} \mathrm{C}$ for 30 minutes, and then $3 \mathrm{ml}$ of the prepared DNS reagent was added, followed by heating in a hot water bath at $100{ }^{\circ} \mathrm{C}$ for 5 minutes. After cooling for about 10 minutes, absorbance was measured at $550 \mathrm{~nm}$.

Two types of cellulose and xylan were used. Regarding Cellulose, Sodium carboxymethyl cellulose (CMC) purchased from Sigma Aldrich with a molecular weight of 250,000 or less and nano-cellulose from hardwood bleached (NC) supported by Changgang Institute of
Paper Science \& Technology were used. Regarding Xylan, Xylan from oat spelts (Xylan-O) and xylan from beech wood (Xylan-B) purchased from sigma aldrich with a molecular weight of less than 35,000 were selected and experimented.

To check the activity of termite intestinal enzymes against the substrate, the amount of the substrate was increased while checking the content of reducing sugars that are decomposed by the activity of the enzyme, and then the termite intestinal enzyme (T1) was compared with the conventional xylanase (X1) and the activity performance against the substrate was analyzed. The xylanase used as a control was purchased from Sigma Aldrich, and all reagents used in all experiments used a grade of 1 or higher.

\subsection{Measurement of inhibitory activity of medicinal plant extracts to xylanase}

An experiment was conducted to select medicinal plant extracts with xylanase-inhibiting performance using extracted termite intestinal enzymes. Medicinal plant extracts were prepared by extracting 628 medicinal plants native to Korea and abroad with methanol. For the termite intestinal enzyme inhibition experiment, a DNS reducing sugar experiment was used as reference. The purpose of this study was to search for medicinal plant extracts that inhibit the enzyme's substrate decomposition activity by adding the medicinal plant extracts during the course of the reaction between the enzyme and the substrate. Through DNS experiments, $10 \mu \mathrm{l}$ of medicinal plant extract was added to $500 \mu \mathrm{l}$ of $1 \%$ xylan-B (0.1 M sodium acetate buffer $\mathrm{pH} 7)$, which is a substrate and $390 \mu \mathrm{l}$ of $0.1 \mathrm{M}$ sodium acetate buffer, and then preheated at $50{ }^{\circ} \mathrm{C}$ for 1 minute in a water bath. Then, after adding $100 \mu \mathrm{l}$ of the termite intestinal enzyme at a concentration of $300 \mu \mathrm{g} / \mathrm{ml}$, reacted in a water bath at $50{ }^{\circ} \mathrm{C}$ for 30 minutes, added $3 \mathrm{ml}$ of DNS reagent, heated at $100{ }^{\circ} \mathrm{C}$ for 5 minutes, then cooled at room temperature for 10 minutes, then 
Table 1. GC-MS (GC : 7890A/MSD : 5975C inert, agilent technologies) analysis

\begin{tabular}{cccccccc}
\hline & \multicolumn{2}{c}{$\mathrm{BSM}$} & \multicolumn{3}{c}{ ESM } \\
\hline Rate $\left({ }^{\circ} \mathrm{C} / \mathrm{min}\right)$ & Value $\left({ }^{\circ} \mathrm{C}\right)$ & $\begin{array}{c}\text { Hold Time } \\
(\mathrm{Min})\end{array}$ & $\begin{array}{c}\text { Run Time } \\
(\mathrm{Min})\end{array}$ & Rate $\left({ }^{\circ} \mathrm{C} / \mathrm{min}\right)$ & Value $\left({ }^{\circ} \mathrm{C}\right)$ & $\begin{array}{c}\text { Hold Time } \\
(\text { Min })\end{array}$ & $\begin{array}{c}\text { Run Time } \\
(\text { Min })\end{array}$ \\
\hline \hline & 40 & 0 & 0 & & 40 & 0 & 0 \\
3 & 80 & 4.167 & 17.5 & 5 & 85 & 5 & 14 \\
2 & 150 & 0 & 52.5 & 3 & 110 & 0 & 22.333 \\
20 & 300 & 0 & 60 & 10 & 350 & 0 & 46.333 \\
\hline
\end{tabular}

(BSM : Borneolum Syntheticum methanol extract, ESM : Ephedra sinica methanol extract)

absorbance was measured at a wavelength of $550 \mathrm{~nm}$. The control group was measured the amount of decomposed reducing sugar using methanol, an extraction solvent of medicinal plant extract, and the medicinal plant extract, which showed a lower amount than it, was selected as having inhibitory activity.

\subsection{Measurement of contact insecticidal concentration and feeding inhibition rate of medicinal plant extract against termites}

In order to measure the contact insecticidal concentration of the medicinal plant extract against termites, it was investigated whether the selected medicinal plant extract showed activity against termites. 30 termites were used, and medicinal plant extracts were dispensed into filter paper at concentrations of $50,10,5,1$, and $0.5 \mathrm{mg} / \mathrm{ml}$, dried to remove the solvent sufficiently and supplied moisture. Moisture was supplied in a spray form using distilled water. The death of termites was observed and counted for 96 hours, and the experiment was conducted without supplementing dead termites.

In order to confirm the feeding inhibition rate of the selected medicinal plant extract on the termites, the medicinal plant extract at a concentration of 0.5 $\mathrm{mg} / \mathrm{ml}$ was dispensed on filter paper and dried to remove the solvent. While moisture was supplemented with a spray form, the feeding amount of termites was set to methanol as the control group. The termite count was selected as 30 termites, and the termite count was checked every 24 hours to maintain a constant termite count. After the final 120 hours, the weight of the filter paper was measured to compare the feeding amount of termites.

\subsection{GC-MS analysis of Borneolum Syntheticum, Ephedra sinica extract}

Borneolum Syntheticum, Ephedra sinica extracts that inhibit the activity of termite intestinal enzymes were analyzed by GC-MS (GC : 7890A/MSD : 5975C inert, agilent technologies). As a pre-treatment of GC-MS analysis, the extract was filtered using a syringe filter (25 mm MFS, JA), and the injection amount per one time was determined to be $1 \mu \mathrm{l}$ for Borneolum Syntheticum extract and $0.3 \mu \mathrm{l}$ for Ephedra sinica extract and injected using the liquid type direct injection method. DB-1HT $(30 \mathrm{~m} \times 250 \mathrm{~mm} \times 0.1 \mathrm{~mm})$ was used as the column, and the conditions of the oven were the same as those in Table 1.

\section{RESULTS and DISCUSSION}

\subsection{Extracting termites intestinal enzymes and protein quantification}

As a result of measuring the enzyme protein content of termites extracted by the extraction method using solubility with the BCA protein diagnostic kit, the 
Table 2. Protein determination of enzymes extracted from termites

\begin{tabular}{ccccc}
\hline & $\begin{array}{c}\text { Termite weight } \\
(\mathrm{g})\end{array}$ & $\begin{array}{c}\text { Buffer } \\
(\mathrm{ml})\end{array}$ & $\begin{array}{c}\text { Protein content } \\
(\mu \mathrm{g} / \mu \mathrm{l})\end{array}$ & $\begin{array}{c}\text { Protein content per g } \\
(\mu \mathrm{g})\end{array}$ \\
\hline \hline Termite intestinal enzyme & 6.11 & 30.55 & 2.33 & 381.87 \\
\hline
\end{tabular}

concentration of total protein content was $2.33 \mathrm{mg} / \mathrm{ml}$. It was confirmed that the amount of $381.87 \mu \mathrm{g} / \mathrm{g}$ could be extracted when termites were frozen and extracted with a buffer (Table 2).

\subsection{Measurement of the activity of termite intestinal enzymes against substrates}

In order to confirm the activity of the extracted termite intestinal enzyme, its properties were identified through various substrates. Cellulose and xylan were used as substrates, and two types (4 types in total) were selected for the measurement of DNS activity using the activity of the extracted enzyme and in the result. It was confirmed that the activity increased in xylan (Fig. 1). It was confirmed that the amount of reducing sugar produced increased as the amount of substrate addition increased, but in the case of cellulose, the amount of reducing sugar produced was changed little even if the amount of substrate increased. It seems that the enzyme activity is low since cellulose, a substrate, is composed of polysaccharides with a large molecular weight, which makes it difficult to decompose into monosaccharides, reducing sugars.

In the previous experiment, as cellulose was found to have a low decomposition rate with the termite enzyme, xylan, which is hemicellulose, was selected as an additional substrate and compared with xylanase that is sold on the market. When the protein concentration of the enzyme was set to $300 \mu \mathrm{g} / \mathrm{ml}$ and the activity against cellulose and xylan was compared, the activity of the termite intestinal enzyme was less active against xylan than xylanase, but it showed similar results, i.e., it has decomposition activity against xylan.

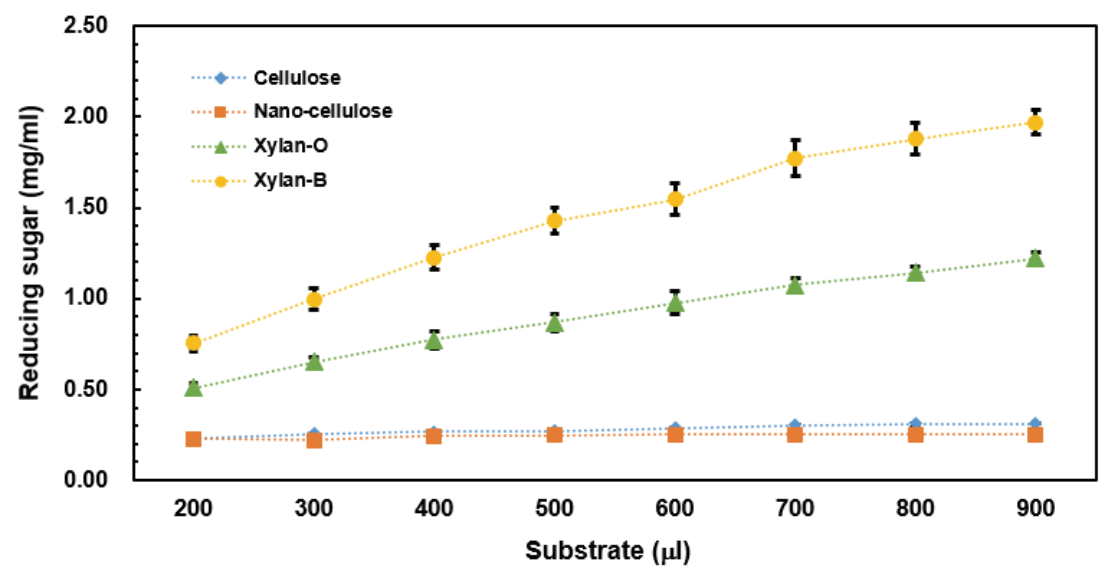

Fig. 1. Termite intestinal enzyme activity on substrate type (cellulose, xylan) and content $(200 \sim 900 \mu l)$. Confirm the activity of the enzyme by using the separated enzyme and increasing the activity according to the substrate and the amount of the substrate. Values are expressed as mean \pm standard deviation. 


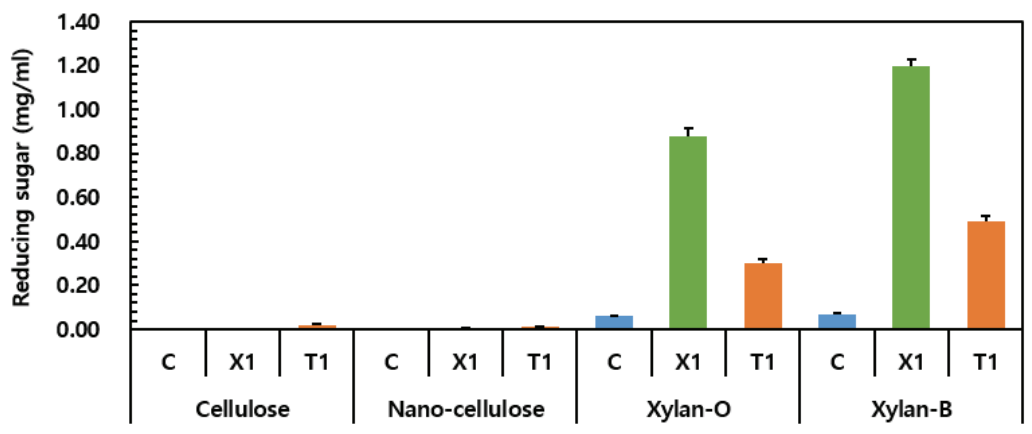

Fig. 2. Comparison of activity on substrates (cellulose, xylan) between xylanase (X1) and termite intestinal enzyme (T1) after protein quantification. Comparative analysis of termite intestinal enzyme and xylanase activity on substrate by measuring the same amount of protein content $(300 \mu \mathrm{g} / \mathrm{m} \ell)$. Values are expressed as mean \pm standard deviation.

(Fig. 2). In particular, it was confirmed that the activity was higher in xylan (Xylan-B) isolated from chestnut than xylan (Xylan-O) isolated from oatmeal. Based on the above, with experiment conditions for identifying medicinal plant extracts that inhibit the activity of termites intestinal enzymes, xylan-B, separated from chestnut trees, was selected as the substrate and $300 \mu \mathrm{g} / \mathrm{ml}$ was determined as the concentration of termites intestinal enzymes.

\subsection{Evaluation of inhibiting the activity of termites intestinal enzymes of medicinal plant extracts}

In order to select medicinal plant extracts that inhibit termite enzyme activity, we explored 628 medicinal plants native in Korea, China, and Japan to find the material that the xylan-B and enzyme protein 300 $\mu \mathrm{g} / \mathrm{ml}$ reaction result produced less reducing sugar than the control group, that is, the material that the inhibitory activity of the extract is high. As a result, Borneolum Syntheticum, Ephedra sinica, Menthol were evaluated to be high in inhibitory activity. As a result of treating the three screened extracts with concentrations $(0.05$, $0.1,0.5 \mathrm{mg} / \mathrm{ml})$, the activity inhibition rate of termite enzyme increased as the concentration increased. At $0.5 \mathrm{mg} / \mathrm{ml}$ concentration, the activity of termite intestinal enzymes was inhibited $16.06 \%$ with Borneolum Syntheticum extract (BSM), $17.73 \%$ with Ephedra sinica extract (ESM), and 25.66\% with Menthol (MTM). (Fig. 3).

\subsection{Measurement results of contact insecticidal concentration and feeding amount of extract of Borneolum Syntheticum, Ephedra sinica, Menthol on termites}

In order to measure the contact insecticidal concentration of Borneolum Syntheticum, Ephedra sinica, Menthol extracts, the dead number of insects by concentration was investigated. In the case of Borneolum Syntheticum extract, all termites died after 48 hours at a concentration of $10 \mathrm{mg} / \mathrm{ml}$ or more and in the case of Ephedra sinica extract at a concentration of $50 \mathrm{mg} / \mathrm{ml}$. In particular, in the case of Menthol, they all died within 1 hour at a concentration of $1 \mathrm{mg} / \mathrm{ml}$ or more and the contact insecticidal effect is high-efficiency on termites even at a small concentration of it (Table 3).

In the feeding amount research conducted with 0.5 


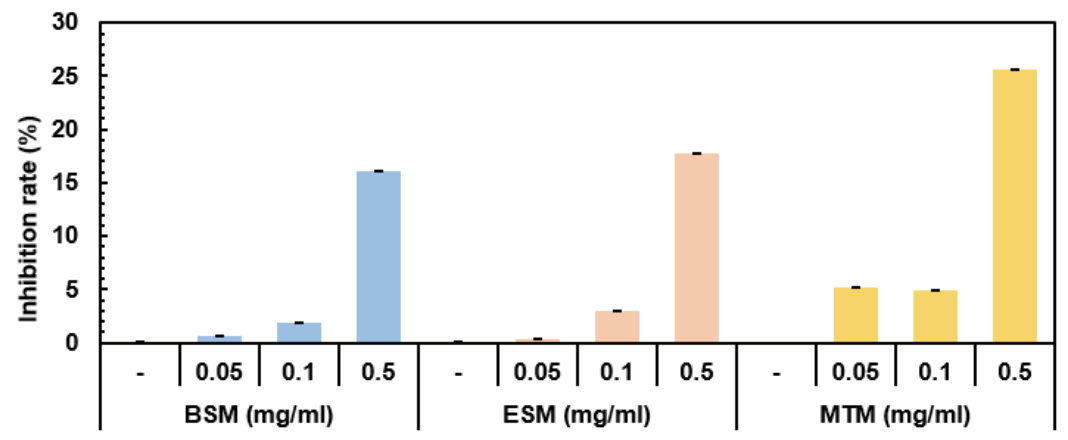

Fig. 3. Inhibition of activation of termite intestinal enzyme substrates by treatment of BSM ESM and MTM. The inhibition rate of termite intestinal enzyme activity was $0.5 \mathrm{mg} / \mathrm{ml}$ to $16.06 \%$ (BSM), $17.73 \%$ (ESM) and $25.66 \%$ (MTM) respectively. Values are expressed as mean \pm standard deviation. (BSM : Borneolum Syntheticum methanol extract, ESM : Ephedra sinica methanol extract, MTM : Menthol methanol extract).

Table 3. Termite contact insecticidal effect on BSM, ESM and MTM for 120 hours

\begin{tabular}{|c|c|c|c|c|c|c|c|c|c|}
\hline \multirow{2}{*}{\multicolumn{2}{|c|}{$(\mathrm{mg} / \mathrm{ml})$}} & \multicolumn{8}{|c|}{ Time (hr) } \\
\hline & & 1 & 2 & 12 & 24 & 48 & 72 & 96 & 120 \\
\hline \multicolumn{2}{|c|}{ Control $(\mathrm{MeOH})$} & 0 & 0 & 1 & 1 & 0 & 0 & 1 & 0 \\
\hline \multirow{5}{*}{ BSM } & 50 & 0 & 1 & 24 & 1 & 4 & - & - & - \\
\hline & 10 & 2 & 0 & 16 & 0 & 12 & - & - & - \\
\hline & 5 & 0 & 0 & 1 & 0 & 0 & 0 & 0 & 0 \\
\hline & 1 & 0 & 0 & 0 & 0 & 0 & 0 & 1 & 0 \\
\hline & 0.5 & 0 & 0 & 0 & 0 & 0 & 0 & 2 & 0 \\
\hline \multirow{5}{*}{ ESM } & 50 & 0 & 1 & 0 & 15 & 14 & - & - & - \\
\hline & 10 & 0 & 0 & 0 & 0 & 0 & 0 & 0 & 0 \\
\hline & 5 & 0 & 0 & 0 & 0 & 0 & 0 & 0 & 0 \\
\hline & 1 & 0 & 0 & 0 & 0 & 0 & 0 & 0 & 0 \\
\hline & 0.5 & 0 & 0 & 1 & 0 & 0 & 0 & 0 & 0 \\
\hline \multirow{5}{*}{ MTM } & 50 & 30 & - & - & - & - & - & - & - \\
\hline & 10 & 30 & - & - & - & - & - & - & - \\
\hline & 5 & 30 & - & - & - & - & - & - & - \\
\hline & 1 & 30 & - & - & - & - & - & - & - \\
\hline & 0.5 & 0 & 0 & 0 & 0 & 2 & 2 & 0 & 0 \\
\hline
\end{tabular}

(BSM : Borneolum Syntheticum methanol extract, ESM : Ephedra sinica methanol extract, MTM : Menthol methanol extract)

$\mathrm{mg} / \mathrm{ml}$ concentration of extracts to measure the inhibition rate of feeding of the extracts of Borneolum Syntheticum, Ephedra sinica, Menthol, the feeding amount of termites was significantly more reduced in the group treated with the extracts than that in the control group
(Fig. 4). In the case of Borneolum Syntheticum extract, it showed a feeding amount of about $73.0 \%$ compared to the control group, $72.2 \%$ for Ephedra sinica, and $67.4 \%$ for Menthol extract. It was inferred that each of the extracts contained components that inhibit the 


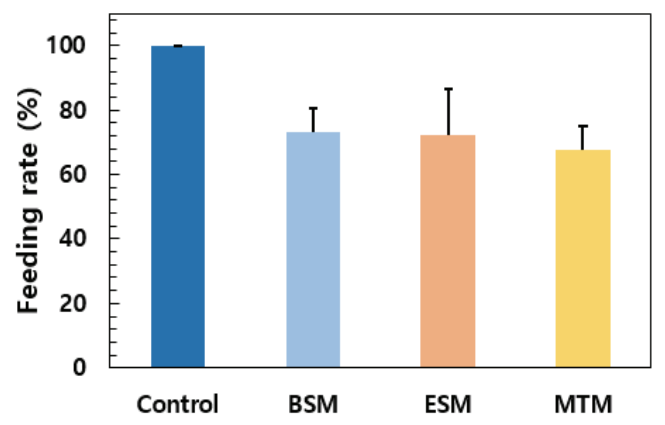

Fig. 4. Termite filter paper intake was measured by treating BSM, ESM and MTM. After incubating the termites for 120 hours, the weight of the filter paper was measured to confirm the intake. As a result of confirming the intake of termites, $72.96 \%$ of BSM, $72.18 \%$ of ESM and $67.42 \%$ of MTM were consumed compared to control. Values are expressed as means \pm standard deviation. (BSM : Borneolum Syntheticum methanol extract, ESM : Ephedra sinica methanol extract, MTM : Menthol methanol extract).

termite feeding activity by reducing the amount of feed by the three extracts. In the course of the termite feeding activity experiment, the termite feeding amount was greatly affected by the condition of the termite and the external environment. Therefore, it is important to maintain the environment so that they can be compared with each other by maintaining a constant temperature and humidity when studying the termite feeding amount (Zukowski AND Su, 2019).

\subsection{GC-MS result analysis of Borneolum Syntheticum, Ephedra sinica extract}

One of the medicinal plant extracts selected in this study, Menthol, has already been reported. Menthol is a crystal obtained by refining and cooling Mentha arvensis. The constituents are reported to be Menthol (Shasany et al., 2000), and the activities of Menthol are reported to have insecticidal effects, antioxidant effects, and antibacterial effects against ticks (Karamaouna et al., 2013; Rozza et al., 2014; Talebi et al., 2014). Therefore, the composition analysis was performed on two substances except Menthol.

As a result of GC-MS analysis, the main components of each Borneolum Syntheticum, Ephedra sinica extracts were clearly identified. As the main components of Borneolum Syntheticum extract, Camphene, Isoborneol, 1-Methyl-4-(1-methylethyl)-1,3-cyclohexadiene, Borneol, (1S)-2,2-Dimethyl-3-methylene-bicyclo[2.2.1]heptane, Anthraquinone-2-carboxylic acid etc. were identified (Table 4).

Camphene is a substance extracted in the form of essence oil, and its antibacterial activity and insecticidal effect against beetles have been reported (Feng et al., 2020; Ibrahim et al., 2020; Sayout et al., 2020) and Isoborneol is known to have activity on a dry eye syndrome among diabetes complications (Ai et al., 2019). In the case of Borneol, it has been reported to have an antioxidant effect and an insecticidal effect on beetles

Table 4. The main components of BSM (Borneolum Syntheticum methanol extract) identified using GC-MS

\begin{tabular}{ccccc}
\hline $\begin{array}{c}\text { Ret. Time } \\
\text { (Min) }\end{array}$ & Area & Name & $\begin{array}{c}\text { Molecular } \\
\text { Weight }\end{array}$ & $\begin{array}{c}\text { Molecular } \\
\text { Formular }\end{array}$ \\
\hline \hline 17.371 & $278.4 \times 10^{6}$ & Borneol & 154 & $\mathrm{C}_{10} \mathrm{H}_{18} \mathrm{O}$ \\
15.898 & $261.2 \times 10^{6}$ & Isoborneol & 154 & $\mathrm{C}_{10} \mathrm{H}_{18} \mathrm{O}$ \\
16.595 & $214.9 \times 10^{6}$ & 1-Methyl-4-(1- methylethyl)-1,3-cyclohexadiene & 136 & $\mathrm{C}_{10} \mathrm{H}_{16}$ \\
15.3 & $126.4 \times 10^{6}$ & Camphene & 136 & $\mathrm{C}_{10} \mathrm{H}_{16}$ \\
18.586 & $4.8 \times 10^{6}$ & (1S)-2,2-Dimethyl- 3- methylene - bicyclo [2.2.1] heptane & 136 & $\mathrm{C}_{10} \mathrm{H}_{16}$ \\
18.738 & $1.0 \times 10^{6}$ & Anthraquinone-2-carboxylic acid & 252 & $\mathrm{C}_{5} \mathrm{H}_{5} \mathrm{IN}_{2} \mathrm{O}_{2}$ \\
\hline
\end{tabular}


Jeung-Min LEE $\cdot$ Young Hee KIM $\cdot$ Jin Young HONG $\cdot$ BoA LIM $\cdot$ Ji Hee PARK

Table 5. The main components of ESM (Ephedra sinica methanol extract) identified using GC-MS

\begin{tabular}{ccccc}
\hline $\begin{array}{c}\text { Ret. Time } \\
\text { (Min) }\end{array}$ & Area & Name & $\begin{array}{c}\text { Molecular } \\
\text { Weight }\end{array}$ & $\begin{array}{c}\text { Molecular } \\
\text { Formular }\end{array}$ \\
\hline \hline 20.466 & $71.2 \times 10^{6}$ & 4-Methyl-1-Indanone & 146 & $\mathrm{C}_{10} \mathrm{H}_{10} \mathrm{O}$ \\
34.999 & $50.4 \times 10^{6}$ & (Z)-9-Octadecenamide & 281 & $\mathrm{C}_{18} \mathrm{H}_{35} \mathrm{NO}$ \\
40.431 & $24.7 \times 10^{6}$ & 17-Pentatriacontene & 491 & $\mathrm{C}_{35} \mathrm{H}_{7} 0$ \\
20.131 & $24.1 \times 10^{6}$ & Phenmetrazine & 177 & $\mathrm{C}_{11} \mathrm{H}_{15} \mathrm{NO}$ \\
27.055 & $10.5 \times 10^{6}$ & 7-Methoxy-2H-1-benzo pyran-2-one & 176 & $\mathrm{C}_{10} \mathrm{H}_{8} \mathrm{O}_{3}$ \\
22.069 & $9.9 \times 10^{6}$ & Benzaldehyde & 106 & $\mathrm{C}_{7} \mathrm{H}_{6} \mathrm{O}$ \\
\hline
\end{tabular}

as an aromatic substance present in herbs (Kasrati et al., 2015; Mühlbauer et al., 2003). In the case of 1-Methyl-4-(1-methylethyl)-1,3-cyclohexadiene, the insecticidal effect on the beetle has also been reported, and in the analysis results of Borneolum Syntheticum extract, the substances that reported the insecticidal effect on the beetle accounted for the majority.

As the main components of Ephedra sinica extract, 4-Methyl-1-Indanone, (Z)-9-Octadecenamide, 17-Penta triacontene, Phenmetrazine, 7-Methoxy-2H-1-benzo pyran2-one, Benzaldehyde, etc. were identified (Table 5).

Among the substances analyzed in Ephedra sinica, 4-Methyl-1-Indanone is known as a substance found in the essential oil part extracted from avocado seeds (Durak and Aysu, 2015), and in the case of (Z) -9Octadecenamide, it has been reported to have a protective effect on nerve cells (Gugnani et al., 2018). 17-Pentatriacontene is primarily known as a substance found in plant root extracts and has been reported as an aromatic compound (Sen et al., 2017; Tayade et al., 2013).

\section{CONCLUSION}

The purpose of this study was to identify intestinal enzyme activity inhibitory substances of termites and to search for extracts from medicinal plants native in Korea and abroad that have mothproof and insecticidal effects on termites. The plant cell wall of wood is com- posed of cellulose and hemicellulose, which are polymer polysaccharides, and is used as the main energy source of termites. Based on these contents, we tried to select medicinal plant extracts that inhibit the activity of enzymes in the process of decomposing and absorbing the cellulose or hemicellulose of wood using the enzymes of microorganisms present in the intestine or Wood decay fungi.

As a result of extracting the termite intestinal enzyme and confirming the activity on cellulose and xylan substrates, the amount of reducing sugars produced in the xylan substrate was significantly increased, and the similar results were observed when compared with xylanase, the control group.

As Cellulose, a polymer polysaccharide, is difficult for the termite intestinal enzymes to degrade into reducing sugars, xylan was selected as a substrate. As a result of targeting extracts of 628 medicinal plants native in Korea, China, and Japan through experiments to select medicinal plant extracts that inhibit the activity between termite intestinal enzymes and substrates, 3 types of medicinal plant extracts were confirmed to inhibit the activity of the termite intestinal enzyme against xylan.

In the evaluation results of concentrations of Borneolum Syntheticum, Ephedra sinica, Menthol extracts that have been shown to have an inhibitory effect on enzyme activity against Xylan, the activity of termite intestinal enzymes was inhibited as much as Borneolum Syntheticum 16.06\%, Ephedra sinica 17.73\%, Menthol 25.66\% 
at the highest concentrations of $0.5 \mathrm{mg} / \mathrm{ml}$. As a result of examining the medicinal plant extracts on the contact insecticidal effect and the amount of feeding on termites, in the case of Menthol, the insecticidal activity was confirmed within 1 hour at $1 \mathrm{mg} / \mathrm{ml}$ or more, in the case of Borneolum Syntheticum was confirmed at 10 $\mathrm{mg} / \mathrm{ml}$ and in the case of Ephedra sinica was confirmed at $50 \mathrm{mg} / \mathrm{ml}$ within 48 hours.

In the results of measuring the feeding amount of termite, the feeding amount was decreased as much as $72.96 \%$ with Borneolum Syntheticum, $72.18 \%$ with Ephedra sinica, and $67.42 \%$ with Menthol compared to the control group. Thus, it was confirmed that the feeding amount of termite was decreased when the medicinal plant extract was treated.

In the screening study of medicinal plant extracts based on the previous termite intestinal enzyme activity study, the extracts of Borneolum Syntheticum, Ephedra sinica, Menthol inhibited the activity of termite enzymes and the effect of reducing the feeding amount on termites was apparent. Some components of these extracts have been reported to have an insecticidal effect, and Menthol has been found to have an insecticidal effect against ticks and Borneolum Syntheticum does against beetles. From the component analysis results using GC-MS, it was confirmed that Ephedra sinica had no previously reported insecticidal effect component. It was judged that the selected three medicinal plant extracts were new substances having an insecticidal effect on termites. Borneolum Syntheticum, Ephedra sinica, Menthol extract are considered to be candidates with sufficient potential as termite insecticides if the human and environmental safety, as well as material stability is secured through further research.

\section{ACKNOWLEDGMENT}

This study was conducted with the support of the research and development project of Cultural Heritage
(R\&D), National Research Institute of Cultural Heritage Administration of Korea.

\section{REFERENCES}

Aanen, D.K. 2006. As you reap, so shall you sow: coupling of harvesting and inoculating stabilizes the mutualism between termites and fungi. Biology Letters 2(2): 209-212.

Ai, X., Hou, Y., Wang, X., Wang, X., Liang, Y., Zhu, Z., Wang, P., Zeng, Y., Li, X., Lai, X., Meng, X., Li, Q. 2019. Amelioration of dry eye syndrome in $\mathrm{db} / \mathrm{db}$ mice with diabetes mellitus by treatment with Tibetan medicine formula Jikan Mingmu Drops. Journal of Ethnopharmacology 241: 111992.

Ben Guerrero, E., Arneodo, J., Bombarda Campanha, R., Abrão de Oliveira, P., Veneziano Labate, M.T., Regiani Cataldi, T., Campos, E., Cataldi, A., Labate, C.A., Martins Rodrigues, C., Talia, P. 2015. Prospection and evaluation of (Hemi) cellulolytic enzymes using untreated and pretreated biomasses in two argentinean native termites. PLOS ONE 10(8): e0136573.

Chung, Y.J., Kim, S.H., Kim, Y.J., Yu, J.S. 2015. Applicability study on Reticulitermes speratus kyushuensis (Isoptera: Rhinotermitidae) colony eliminator to preserve wooden cultural heritage. Journal of the Korean Wood Science and Technology 43(6): 818-825.

Cosgrove, D.J. 2005. Growth of the plant cell wall. Nature Reviews Molecular Cell Biology 6(11); 850-861.

Durak, H., Aysu, T. 2015. Effect of pyrolysis temperature and catalyst on production of bio-oil and bio-char from avocado seeds. Research on Chemical Intermediates 41(11): 8067-8097.

Feng, Y.X., Wang, Y., Geng, Z.F., Zhang, D., Almaz, B., Du, S.S. 2020. Contact toxicity and repellent efficacy of Valerianaceae spp. to three stored- 
product insects and synergistic interactions between two major compounds camphene and bornyl acetate. Ecotoxicology and Environmental Safety 190: 110106.

Gugnani, K.S., Vu, N., Rondón-Ortiz, A.N., Böhlke, M., Maher, T.J., Pino-Figueroa, A.J. 2018. Neuroprotective activity of macamides on manganese-induced mitochondrial disruption in U-87 MG glioblastoma cells. Toxicology and Applied Pharmacology 340(1): 67-76.

Hadi, Y.S., Massijaya, M.Y,. Abdillah, I.B., Pari, G., Arsyad, W.O.M. 2020. Color change and resistance to subterranean termite attack ofmangium (Acacia mangium) and sengon (Falcataria moluccana) smoked wood. Journal of the Korean Wood Science and Technology 48(1): 1-11.

Ibrahim, M.A., Cantrell, C.L., Jeliazkova, E.A., Astatkie, T., Zheljazkov, V.D. 2020. Utilization of nutmeg (Myristica fragrans Houtt.) seed hydrodistillation time to produce essential oil fractions with varied compositions and pharmacological effects. Molecules 25(3): E565.

Karamaouna, F., Kimbaris, A., Michaelakis, A., Papachristos, D., Polissiou, M., Papatsakona, P., Tsora, E. 2013. Insecticidal activity of plant essential oils against the vine mealybug, Planococcus ficus. Journal of Insect Science 13(1). Doi: 10.1673/031.013.14201.

Kasrati A1, Alaoui Jamali C1, Bekkouche K1, Wohlmuth H2, Leach D3, Abbad A1. 2015. Comparative evaluation of antioxidant and insecticidal properties of essential oils from five Moroccan aromatic herbs. Journal of Food Science and Technology 52(4): 2312-2319.

Miller, G.L. 1959. Use of Dinitrosalicylic acid reagent for determination of reducing sugar. Analytical Chemistry 31(3): 426-428.

Mühlbauer, R.C., Lozano, A., Palacio, S., Reinli, A., Felix, R. 2003. Common herbs, essential oils, and monoterpenes potently modulate bone metabolism. Bone 32(4): 372-380.

Mun, S.P., Nicholas, D.D. 2017. Effect of proanthocyanidin-rich extracts from Pinus radiata bark on termite feeding deterrence. Journal of the Korean Wood Science and Technology 45(6): 720-727.

National Research Institute of Cultural Heritage, 2016. Investigation on biological species harmful to wooden cultural heritage (Daejeon AND Jeju). Daejeon, Korea.

Rozza, A.L., Meira de Faria, F., Souza Brito, A.R., Pellizzon, C.H. 2014. The gastroprotective effect of menthol: involvement of anti-apoptotic, antioxidant and anti-inflammatory activities. PLoS One 9(1): e86686.

Sayout, A., Ouarhach, A., Rabie, R., Dilagui, I., Soraa, N., Romane, A. 2020. Evaluation of antibacterial activity of Lavandulapedunculata subsp. atlantica (Braun-Blanq.) romo essential oil and selected terpenoids against resistant bacteria strains-structureactivity relationships. Biochemistry \& Molecular Biology 17(1): e1900496.

Sen, S., Dehingia, M., Talukdar, N.C., Khan, M. 2017. Chemometric analysis reveals links in the formation of fragrant bio-molecules during agarwood (Aquilaria malaccensis) and fungal interactions. Scientific Reports 14(7): 44406.

Shasany, A.K., Khanuja, S.P., Dhawan, S., Kumar, S. 2000. Positive correlation between menthol content and in vitro menthol tolerance in Mentha arvensis L. cultivars. Journal of Biosciences 25(3): 263-266.

Talebi, S., Sabokbar, A., Riazipour, M., Saffari, M. 2014. Comparison of the in vitro effect of chemical and herbal mouthwashes on Candida albicans. Jundishapur Journal of Microbiology 7(12): e12563.

Tarayre, C., Bauwens, J., Brasseur, C., Mattéotti, C., Millet, C., Guiot, P.A., Destain, J., Vandenbol, M., Portetelle, D., De Pauw, E., Haubruge, E., Francis, F., Thonart, P. 2015. Isolation and cultivation of 
Exploration of Preservatives that Inhibit Wood Feeding by Inhibiting Termite Intestinal Enzyme Activity

xylanolytic and cellulolytic Sarocladium kiliense and Trichoderma virens from the gut of the termite Reticulitermes santonensis. Environmental Science and Pollution Research 22(6): 4369-4382.

Tayade, A.B., Dhar, P., Kumar, J., Sharma, M., Chauhan, R.S., Chaurasia, O.P., Srivastava, R.B. 2013. Chemometric profile of root extracts of Rhodiola imbricata Edgew. with hyphenated gas chromatography mass spectrometric technique. RLOS ONE 8(1): e52797.

Terrett, O.M., Dupree, P. 2019. Covalent interactions between lignin and hemicelluloses in plant secon- dary cell walls. Current Opinion in Biotechnology 56: $97-104$.

Wu, C.C., Tsai, C.L., Liang, W.R., Takematsu, Y., Li, H.F. 2019. Identification of subterranean termite genus, Reticulitermes (Blattodea: Rhinotermitidae) in Taiwan. Journal of Economic Entomology 112(6): 2872-2881.

Zukowski, J., Su, N.Y. 2019. Cuticular permeability, percent body water loss, and relative humidity equilibria comparisons of four termite species. Journal of Insect Science 19(5): 1-6. 


\title{
APPENDIX
}

\author{
(Korean Version)
}

\section{흰개미 장내 효소 활성 억제로 목재의 섭식을 저해하는 보존 처리제의 탐색}

초록 : 우리나라는 울릉도 및 제주도를 포함한 전국에서 흰개미에 의한 목조 문화재의 피해가 보고되어 있다. 흰개미에 의한 피해를 감소시키고자 훈증처리나 토양에 약물을 처리하여 살충 및 방충을 하는 것이 대부분이며 비용과 안전성의 문제로 인해 점점 처리하는 횟수가 감소하는 추세이다. 이런 상황을 대처하기 위해 새로운 방법이 필요한 실정이므로 전남 신안에서 채집한 흰개미에서 일개미만 선별하여 효소를 추출한 후 목재 구성성분인 cellulose와 hemicellulose의 xylan을 기질로 하여 효소 활성을 측정한 결과, 분자량이 큰 cellulose 보다 xylan에서 흰개미 장내 효소의 활성이 크게 나타났다. 그러므로 본 연구에서 는 xylan을 기질로 하여 흰개미 장내 효소의 활성을 억제하는 약용식물 추출물 600 여 종을 탐색한 결과, 용뇌, 마황, 박하뇌에서 억제효과가 크게 나타났다. 선별된 용뇌(Borneolum Syntheticum), 마황(Ephedra sinica), 박하뇌(Menthol) 추출물은 흰개미 장내 효소의 활성을 억제할 뿐만 아니라 직접 처리한 결과에서도 살충활성 및 섭식 저해 효과가 있음을 확인하였다.

\section{1. 서 론}

우리나라의 흰개미 분포 형태는 일본흰개미(Reticulitermes speratus kyushuensis)가 대부분을 차지하고 있으나 최근 칸몬흰개 미(Reticuliternes kanmonensis)가 발견되고 있으며 지역적으로는 울릉도 및 제주도를 포함하여 전국에서 흰개미에 의한 건축물 의 피해가 보고되고 있다(National Research Institute of Cultural Heritage, 2016). 흰개미의 활동은 주로 3월에 시작하여 10 11 월쯤 기온의 하강으로 토양 깊숙이 이동하여 생존하는 습성이 일반적이나 사람이 생활하는 목조 건축물에서는 겨울철 내부 난방으로 인해 흰개미가 겨울에도 활동하는 것이 확인되었으며 피해가 급속하게 증가한다(Wu et al., 2019).

사찰이나 서원의 경우 건물과 건물 간의 배치와 건물의 크기에 따라 흰개미나 미생물에 의한 생물피해에 취약점을 가지고 있으며 피해 정도에 따라 방제 또는 보수 등의 처리를 하고 있다. 피해 정도가 심한 경우 새로운 부재를 이용하여 건물을 새로 복원하는 방법을 이용하거나 주변의 토양에 약제를 처리하여 흰개미의 접근을 제한하는 방법을 이용하고 있으나 복원 비용이나 처리 시간 증가와 같은 요소를 가지고 있다. 피해가 초기 단계일 경우에는 건물에 훈증 소독 또는 방충제를 도포하거나 주변에 흰개미 트랩을 설치하여 흰개미 활동 여부를 확인하여 대처하고 있다(Chung et al., 2015; Hadi et al., 2020). 하지만 트랩도 관리가 소홀하면 흰개미의 유인을 유도하여 거점으로 역할이 전환되는 위험성을 가지고 있으며, 훈증처리 및 방충제 처리시 사용되는 약제는 화학약품이 대부분으로 인체에도 피해를 주어 화학약품에 대한 사용 횟수가 감소하는 추세이며 보완할 새로운 방법이 필요한 실정이다.

흰개미의 주요 섭식 대상인 목재는 식물의 세포벽이 구조적으로 단단한 구성을 이루고 있으며, 세포벽의 구성성분으로는 cellulose, hemicellulose, lignin 등으로 구성되어 있다(Cosgrove, 2005; Terrett and Dupree, 2019). 그 중 cellulose와 hemicellulose는 다당류로써 당의 종류와 결합사슬에 따라 구분되며, cellulose는 D-glucose의 직선형 사슬로 이루어진 다당체 로 나선이나 곁사슬이 없고 사슬 내 hydroxyl기들이 수소결합을 형성하여 결합이 단단하고 강하다. 반면에 hemicellulose는 glucose 뿐만 아니라 xylose, maltose, galactose 등 몇 가지 당류로 이루어진 다당체로 cellulose와 달리 곁사슬이 많이 형성되어 결합이 유연하다. Hemicellulose는 부후균이나 곤충의 장내에 존재하는 미생물에 의해 분해되어 에너지원으로 이용되고 있다 (Aanen, 2006; Ben Guerrero et al., 2015; Tarayre et al., 2015). 흰개미가 섭식한 목재를 장내 미생물총이 저분자 당으로 분해하여 에너지원으로 이용하는데, 이 때 이들 미생물의 효소 활성이 목재 섭식률에도 영향을 미칠 것으로 판단된다(Mun and Nicholas, 2017).

따라서 본 연구에서는 흰개미 장내 효소와 세포벽 주성분인 기질에 대한 활성을 통해 작용기전을 확인하고 그 작용기전을 억제하는 약용식물 추출물을 선별하고자 하였다. 약용식물 추출물로는 한국, 중국, 일본에 자생하는 600여 종의 약용식물에서 추출하여 사용하였으며, 흰개미 장내 효소 활성 억제 추출물을 선별하여 직접 흰개미의 섭식 및 살충효과를 확인하고 그 성분을 분석하여 흰개미에 대한 방충 및 살충용 목재 보존 처리제로써 가능성을 확인하고자 하였다. 
Exploration of Preservatives that Inhibit Wood Feeding by Inhibiting Termite Intestinal Enzyme Activity

\section{2. 재료 및 방법}

\section{1. 흰개미 장내 효소 추출 및 단백질 정량}

실험에 사용된 모든 흰개미는 전라남도 신안군 김환기 고택을 대상으로 하는 목조문화재 관련 생물피해 조사과정 중 부근 그루터기에서 발견한 일본흰개미를 채집하여 이용하였다.

효소 추출방법으로는 용해도를 이용한 추출 방식을 선택하였다. 흰개미 중 일개미를 선별하여 $6.11 \mathrm{~g}$ 을 $-40{ }^{\circ} \mathrm{C}$ 에서 동결시켜 파쇄한 후 $0.1 \mathrm{M}$ sodium acetate buffer (pH 7)를 흰개미 무게 $1 \mathrm{~g}$ 당 $5 \mathrm{ml}$ 를 첨가하여 실온에서 24시간 교반하여 충분히 효소를 추출한 후 여과지로 여과하여 흰개미 장내 효소로 이용하였다.

추출한 흰개미 장내 효소에 대한 단백질 함량을 측정하기 위해 Pierce ${ }^{\mathrm{TM}} \mathrm{BCA}$ protein assay kit (Thermo, USA)를 이용한 정량법을 선택하였으며, 비교 정량하기 위한 단백질로 bovine serum albumin (BSA)을 선택하였다. 정량법에 따라 흰개미 장내 효소와 비교 단백질 $\mathrm{BSA}$ 를 반응 시약과 $37^{\circ} \mathrm{C}$ 에서 30 분간 반응시킨 후 Microplate readers (TECAN, CHE)로 흡광도(562 $\mathrm{nm})$ 를 측정하였다. 비교 단백질인 $\mathrm{BSA}$ 함량을 정량곡선으로 하고 흰개미 장내 효소의 단백질을 정량하였다.

\section{2. 기질에 대한 흰개미 장내 효소의 활성 측정}

흰개미 장내 효소의 활성을 알아보고자 기질은 cellulose와 hemicellulose인 xylan을 선택하였으며, 분해되는 환원당의 함량을 측정하고자 Miller(1959)의 DNS(3,5-dinitrosalicylic acid) 환원당 정량 실험을 선택하여 실시하였다. Miller의 DNS 환원당 실험은 환원당과 DNS가 반응하여 환원되어 생성된 3-amino-5-nitrosalicylic acid의 흡광도를 측정하여 당을 정량하는 방식이다 (Miller, 1959). DNS 시약 제조는 증류수 $1,416 \mathrm{ml}$ 에 DNS $10.6 \mathrm{~g}$ 과 NaOH $19.8 \mathrm{~g}$ 을 첨가하여 녹인 다음 rochelle salts $306 \mathrm{~g}$ 과 phenol $7.6 \mathrm{~g}$ 을 첨가 후 $\mathrm{Na}^{+}$metabisulfite $8.3 \mathrm{~g}$ 을 넣고 24시간 교반하여 DNS 시약으로 사용하였다.

흰개미 장내 효소 활성 실험 방법으로는 $1 \%$ 의 cellulose, xylan과 같은 기질을 $500 \mu l$ 와 $0.1 \mathrm{M}$ sodium acetate buffer 400 $\mu \mathrm{l}$ 를 함께 첨가한 후 $50^{\circ} \mathrm{C}$ 에서 물중탕으로 1 분간 예열한다. 예열한 기질과 버퍼에 효소 $100 \mu \mathrm{l}$ 를 첨가하여 $50^{\circ} \mathrm{C}$ 에서 30 분간 효소와 기질을 반응을 시킨 후 제조된 DNS 시약 $3 \mathrm{ml}$ 을 첨가하여 $100^{\circ} \mathrm{C}$ 에서 5 분간 중탕으로 가열하였다. 10 분 정도 냉각시킨 후 $550 \mathrm{~nm}$ 에서 흡광도를 측정하였다.

기질로 사용된 cellulose와 xylan은 각각 2종씩 선별하여 사용하였다. Cellulose는 분자량 250,000 이하로 sigma aldrich에서 구매한 sodium carboxymethyl cellulose (CMC)와 창강제지기술연구소의 지원을 받은 nano-cellulose from hardwood bleached (NC)를 선택하다. Xylan은 분자량 35,000 이하로 sigma aldrich에서 구매한 xylan from oat spelts (Xylan-O)와 xylan from beech wood (Xylan-B) 선택하여 실험하였다.

기질에 대한 흰개미 장내 효소의 활성을 알아보기 위해 기질의 양을 증가시키면서 효소의 활성으로 분해되는 환원당의 함량을 확인한 다음 흰개미 장내 효소(T1)와 기존에 판매하고 있는 xylanase(X1)를 비교하여 기질에 대한 활성 성능을 분석하였 다. 대조군으로 사용한 xylanase는 sigma aldrich에서 구매하였으며, 모든 실험에서 사용한 시약의 경우 모두 일급 이상의 등급을 사용하였다.

\section{3. 약용식물 추출물의 xylanase 저해 활성 측정}

추출된 흰개미 장내 효소를 이용하여 xylanase 저해 성능을 가지는 약용식물 추출물을 선별하기 위한 실험을 하였다. 약용식물 추출물은 국내·외에 자생하는 약용식물 628 종을 methanol에 추출하여 제조하였다. 흰개미 장내 효소 저해 실험은 DNS 환원당 실험을 응용하였으며, 효소와 기질이 서로 반응하는 작용 과정에 약용식물 추출물을 처리하여 효소의 기질분해 활성을 저해하는 약용식물 추출물을 탐색하고자 하였다. DNS 실험을 통해 기질인 $1 \%$ xylan-B (0.1 M sodium acetate buffer pH 7) $500 \mu$ 와 $0.1 \mathrm{M}$ sodium acetate buffer $390 \mu \mathrm{l}$ 에 약용식물 추출물 $10 \mu \mathrm{l}$ 를 첨가한 후 $50^{\circ} \mathrm{C}$ 에서 1 분간 중탕으로 예열하였다. 그 다음 $300 \mu \mathrm{g} / \mathrm{ml}$ 농도의 흰개미 장내 효소를 $100 \mu \mathrm{l}$ 첨가한 후 $50^{\circ} \mathrm{C}$ 에서 30 분간 중탕으로 반응을 시키고 DNS 시약을 $3 \mathrm{ml}$ 첨가하여 $100^{\circ} \mathrm{C}$ 에서 5 분간 가열한 후 10 분간 실온에서 냉각한 다음 $550 \mathrm{~nm}$ 의 파장에서 흡광도를 측정하였다. 대조군은 약용식물 추출물의 추출 용매인 methanol을 이용하며 분해된 환원당의 양을 측정하였으며, 이보다 낮은 양을 나타내는 약용식물 추출물을 저해 활성을 가진 것으로 선별하였다.

2.4. 흰개미에 대한 약용식물 추출물의 접촉 살충 농도 및 섭식 저해율 측정

흰개미에 대한 약용식물 추출물의 접촉 살충 농도를 측정하기 위해 선별된 약용식물 추출물을 흰개미를 대상으로 활성이 나타나는지 확인하였다. 흰개미 30 마리를 이용하였으며, 약용식물 추출물을 농도별 $50,10,5,1,0.5 \mathrm{mg} / \mathrm{ml}$ 로 여과지에 분주한 
후 건조해 용매를 충분히 제거하고 수분을 공급하였다. 수분 공급은 증류수를 이용하여 분무형식으로 처리하였다. 흰개미의 사충수는 96 시간 동안 관찰하여 측정하였으며, 죽은 수에 대한 흰개미 추가는 없이 진행하였다.

선별된 약용식물 추출물의 흰개미에 대한 섭식 저해율을 확인하기 위해 $0.5 \mathrm{mg} / \mathrm{ml}$ 농도의 약용식물 추출물을 filter paper에 분주한 다음 건조해 용매를 제거하였다. 수분은 분무 형태로 보충하면서 흰개미의 섭식 양을 대조군은 methanol로 하였으며, 흰개미의 수는 일개미 30 마리로 선정하고 24 시간마다 흰개미의 수를 체크하여 사멸하는 수만큼 흰개미를 추가하였다. 최종 120 시간 후 여과지의 무게를 측정하여 흰개미의 섭식 양을 비교하였다.

\section{5. 용뇌와 마황 추출물의 GC-MS 분석}

흰개미 장내 효소의 활성을 저해하는 마황과 용뇌 추출물을 GC-MS (GC : 7890A/MSD : 5975C inert, agilent technologies)를 통해 성분을 분석하였다. GC-MS 분석의 전처리로 추출물을 syringe filter $(25 \mathrm{~mm} \mathrm{MFS}, \mathrm{JA})$ 를 이용하여 여과하였으며, 주입량은 1 회당 용뇌 추출물은 $1 \mu \mathrm{l}$ 로 정하고 마황 추출물의 경우 $0.3 \mu 1$ 로 정하여 Liquid type의 직접 주입법으로 주입하였다. Column은 $\mathrm{DB}-1 \mathrm{HT}(30 \mathrm{~m} \times 250 \mathrm{~mm} \times 0.1 \mathrm{~mm})$ 를 이용하였으며, 오븐의 조건은 Table 1의 분석조건과 같다(Table 1).

\section{3. 결과 및 고찰}

\section{1. 흰개미 장내 효소 추출 및 단백질 정량}

용해도를 이용한 추출법으로 추출된 흰개미를 BCA 단백질 진단 키트를 사용하여 흰개미의 효소 단백질 함량을 측정한 결과, 총 단백질 함량의 농도는 $2.33 \mathrm{mg} / \mathrm{ml}$ 이었다. 이는 흰개미를 동결시켜 버퍼로 추출할 경우 $1 \mathrm{~g}$ 당 $387.87 \mu \mathrm{g}$ 의 양을 추출할 수 있는 것으로 확인되었다(Table 2).

\section{2. 기질에 대한 흰개미 장내 효소의 활성도 측정 결과}

추출된 흰개미 장내 효소의 활성도를 확인하고자 여러 기질을 통해 그 특성을 파악하였다. 기질은 cellulose와 xylan을 사용하 였으며, 각각 2종류(총 4종)를 선택하여 추출된 효소의 활성 여부에 대한 DNS 활성을 측정한 결과에서는 xylan에서 활성도가 증가하는 것을 확인하였다(Fig. 1). 기질의 첨가량이 증가할수록 생성되는 환원당의 양이 증가하는 것을 확인하였으나, cellulose 의 경우에는 기질의 양이 증가하여도 생성되는 환원당의 양이 변화가 미비한 것으로 나타났다. 이점은 기질인 cellulose가 분자량이 큰 다당체로 구성되어 있어 단당류인 환원당으로 분해하기 어려워 효소의 활성이 낮은 것으로 판단된다.

앞선 실험을 통해 cellulose는 흰개미 조효소에 낮은 분해능을 갖는 것이 확인되었으므로 hemicellulose인 xylan을 추가 기질로 선택하고 시중에 판매하고 있는 xylanase와 비교·분석하였다. 효소의 단백질 농도를 $300 \mu \mathrm{g} / \mathrm{ml}$ 로 하고 cellulose와 xylan 에 대한 활성을 비교한 결과, 흰개미 장내 효소의 활성이 xylanase보다는 xylan에 대하여 활성이 저조하지만 비슷한 결과를 나타내는 것으로 보아 xylan에 대한 분해 활성이 있는 것을 확인하였다(Fig. 2). 특히 오트밀에서 분리된 xylan (Xylan-O)보다는 밤나무에서 분리된 xylan (Xylan-B)에서 활성이 높은 것을 확인하였다. 위의 내용을 바탕으로 흰개미 장내 효소의 활성을 저해하는 약용식물 추출물을 확인하기 위한 실험조건으로 기질은 밤나무에서 분리된 xylan-B를 흰개미 장내 효소의 농도로는 $300 \mu \mathrm{g} / \mathrm{ml}$ 로 선정하였다.

\section{3. 약용식물 추출물의 흰개미 장내 효소 활성 저해 평가}

흰개미 조효소 활성을 저해하는 약용식물 추출물을 선정하고자 한국, 중국, 일본에 존재하는 약용식물 628 종을 대상으로, xylan-B와 $300 \mu \mathrm{g} / \mathrm{ml}$ 농도의 효소 단백질 반응 결과가 대조군보다 적은 양의 환원당이 생성되는 즉, 억제 활성이 높은 물질을 탐색한 결과, 용뇌, 마황, 그리고 박하뇌 추출물이 활성 억제가 높은 것으로 평가되었다. 스크리닝 된 세가지 추출물을 농도별 $(0.05,0.1,0.5 \mathrm{mg} / \mathrm{ml})$ 로 처리한 결과, 농도가 증가할수록 흰개미 조효소의 활성 억제율이 높아졌고, $0.5 \mathrm{mg} / \mathrm{ml}$ 농도에서 용뇌 추출물(BSM) $16.06 \%$, 마황 추출물(ESM) $17.73 \%$, 박하뇌 추출물(MTM)은 $25.66 \%$ 로 흰개미 장내 효소의 활성을 억제하는 것을 확인하였다(Fig. 3).

3.4. 흰개미에 대한 용뇌, 마황, 박하뇌 추출물의 접촉 살충농도 및 섭식 양 측정 결과

용뇌, 마황 그리고 박하뇌 추출물의 접촉 살충농도를 측정하기 위해 농도별 사충수를 조사하였다. 용뇌 추출물의 경우 10 $\mathrm{mg} / \mathrm{ml}$ 농도 이상, 마황 추출물의 경우 $50 \mathrm{mg} / \mathrm{ml}$ 농도에서 48 시간 이후 흰개미가 전부 죽은 것을 확인하였고, 특히 박하뇌의 경우에는 $1 \mathrm{mg} / \mathrm{ml}$ 이상의 농도에서 1 시간 내 사멸하는 것을 확인하였으며 적은 농도에서도 높은 효율의 흰개미 접촉 살충효과를 
확인하였다(Table 3).

용뇌, 마황, 박하뇌 추출물의 섭식 저해율 측정을 위해 $0.5 \mathrm{mg} / \mathrm{ml}$ 농도의 추출물로 수행한 섭식량 조사 결과에서는 대조군 보다 추출물을 처리한 군에서 흰개미의 섭식량이 감소가 큰 것이 확인되었다(Fig. 4). 용뇌 추출물의 경우 대조군 대비 약 $73.0 \%$ 의 섭식량을 보였고 마황 추출물의 경우 $72.2 \%$, 그리고 박하뇌 추출물의 경우에는 $67.4 \%$ 의 섭식량으로 조사되었다. 세 추출물에 의한 섭식량 감소를 통해 각각 추출물에 흰개미의 섭식 활동을 저해하는 성분을 함유하고 있음을 유추하였다. 흰개미의 섭식 활동 실험 과정에서 흰개미의 섭식량은 흰개미의 상태와 외부적인 환경에 영향을 많이 받는 것을 확인하였다. 따라서 흰개미 섭식량 연구 시에는 일정한 온도와 습도를 유지하여 상호간 비교가 가능하도록 환경을 유지하는 것이 중요하다 (Zukowski AND Su, 2019).

\section{5. 용뇌와 마황 추출물의 GC-MS 결과 분석}

이 연구에서 선정한 약용식물 추출물 중 하나인 박하뇌는 그 성분이 이미 보고되어 있다. 박하뇌는 박하(Mentha arvensis)를 정유하여 냉각시켜 얻은 결정체로써 구성성분은 Menthol로 보고되어 있으며(Shasany et al., 2000), 박하뇌의 활성으로는 진드기 에 대한 살충효과 및 항산화, 항균효과가 보고되어 있다(Karamaouna et al., 2013; Rozza et al., 2014; Talebi et al., 2014). 따라서, 박하뇌를 제외한 두 물질을 대상으로 성분분석을 하였다.

GC-MS 분석 결과, 용뇌와 마황 추출물은 각각 주요 성분이 뚜렷하게 나타나는 것이 확인되었다. 용뇌 추출물의 주요 성분으 로는 Camphene, Isoborneol, 1-Methyl-4-(1-methylethyl)-1,3-cyclohexadiene, Borneol, (1S)-2,2-Dimethyl-3-methylenebicyclo[2.2.1]heptane, Anthraquinone-2-carboxylic acid 등으로 동정 되었다(Table 4).

Camphene은 에센스 오일 형태로 추출이 되는 물질이며 항균 활성과 딱정벌레에 대한 살충효과가 보고되어 있으며(Feng et al., 2020; Ibrahim et al., 2020; Sayout et al., 2020), Isoborneol은 당뇨합병증 중 안구건조증에 활성을 가진다고 알려져 있고(Ai et al., 2019) Borneol의 경우에는 허브에 존재하는 방향성 물질로써 항산화 효과 및 딱정벌레에 살충효과를 가진다고 보고되어 있다(Kasrati et al., 2015; Mühlbauer et al., 2003). 1-Methyl-4-(1-methylethyl)-1,3-cyclohexadiene의 경우에도 딱정 벌레에 대한 살충효과가 보고되어 있어 용뇌 추출물의 분석결과에서는 딱정벌레에 대한 살충효과가 보고된 물질이 대다수를 차지하였다.

마황 추출물의 경우 주요 성분으로 4-Methyl-1-Indanone, (Z)-9-Octadecenamide, 17-Pentatriacontene, Phenmetrazine, 7-Methoxy-2H-1-benzo pyran-2-one, Benzaldehyde 등으로 동정 되었다(Table 5).

마황에서 분석된 물질 중 4-Methyl-1-Indanone는 아보카도 씨앗에서 추출된 정유 부분의 물질에서 발견된 물질로 알려져 있으며(Durak and Aysu, 2015), (Z)-9-Octadecenamide의 경우 신경세포에 대한 보호 효과를 가진다고 보고되어 있다(Gugnani et al., 2018). 17-Pentatriacontene는 주로 식물의 뿌리 추출물에서 발견되는 물질로 알려져 있으며 방향성 화합물로 보고되어 있다(Sen et al., 2017; Tayade et al., 2013).

\section{4. 결 론}

본 연구는 흰개미의 장내 효소 활성 억제물질을 확인하고 국내·외에 존재하는 약용식물을 대상으로 흰개미 방충 및 살충효과 를 가지는 추출물을 탐색하고자 하였다. 목재의 식물 세포벽은 고분자 다당체인 cellulose와 hemicellulose로 구성되어 있으며, 흰개미의 주된 에너지원으로 이용되고 있다. 이러한 내용을 바탕으로 흰개미가 부후균이나 장내에 존재하는 미생물의 효소를 이용하여 목재의 cellulose나 hemicellulose를 분해하여 흡수하는 과정에서 효소의 작용을 저해하는 약용식물 추출물을 선별하고 자 하였다.

흰개미 장내 효소를 추출하여 cellulose와 xylan 기질에 대한 활성을 확인한 결과 xylan 기질에서 생성되는 환원당의 양이 확연하게 증가하는 것을 확인하였으며, 대조군인 xylanase를 통해 비교해본 결과에서도 같은 양상의 결과를 확인하였다.

Cellulose가 고분자 다당체로 흰개미 장내 효소가 환원당으로 분해하기가 어렵다는 점에서 xylan을 기질로 선택하였다. 흰개미 장내 효소와 기질간의 활성을 저해하는 약용식물 추출물을 선별하는 실험을 통해 628 종의 한국, 중국, 일본에 자생하는 약용식물의 추출물을 대상으로 한 결과, 3 종류의 약용식물 추출물이 xylan에 대한 흰개미 장내 효소의 활성을 저해하는 것을 확인하였다.

Xylan에 대한 효소 활성 저해 효과가 있는 것으로 확인된 용뇌, 마황과 박하뇌 추출물의 농도별 평가 결과에서 최고 농도인 $0.5 \mathrm{mg} / \mathrm{ml}$ 에서 용뇌 $16.06 \%$, 마황 $17.73 \%$, 박하뇌 $25.66 \%$ 의 비율로 흰개미 장내 효소의 활성을 저해하는 것을 확인하였다. 약용식물 추출물을 흰개미에 대한 접촉 살충효과와 섭식 양에 대하여 알아본 결과, 박하뇌의 경우 $1 \mathrm{mg} / \mathrm{ml}$ 이상에서 1 시간 
이내 살충활성을 확인하였으며, 용뇌는 $10 \mathrm{mg} / \mathrm{ml}$, 마황은 $50 \mathrm{mg} / \mathrm{ml}$ 에서 48 시간 이내 살충활성을 확인하였다.

흰개미 섭식 양을 측정한 결과에서도 대조군 대비 용뇌 $72.96 \%$, 마황 $72.18 \%$, 그리고 박하뇌 $67.42 \%$ 의 섭식 양으로 확인되어 약용식물 추출물을 처리할 경우 섭식 양이 감소하는 것을 확인하였다.

앞선 흰개미 장내 효소 활성 연구를 바탕으로 하여 수행한 약용식물 추출물의 스크리닝 연구에서 선택된 용뇌, 마황, 박하뇌 추출물은 흰개미 조효소의 활성을 저해하고 흰개미에 대한 섭식 양의 감소 효과가 뚜렷이 나타났다. 이 추출물들의 일부 성분은 살충효과가 보고되었는데, 박하뇌는 진드기, 용뇌는 딱정벌레에 대한 살충효과가 있는 것으로 밝혀졌다. GC-MS를 활용한 성분분석 결과에서 마황은 기 보고된 살충효과 성분이 없는 것으로 확인되었다. 선택된 3종의 약용식물 추출물은 흰개미에 대한 살충효과를 가지는 새로운 물질이라고 판단하였다. 용뇌, 마황 그리고 박하뇌 추출물은 추가적인 연구를 통해 인체 및 환경 안전성과 재질 안정성을 확보한다면 흰개미 살충제로서의 충분한 가능성을 가진 후보물질이라고 생각한다. 